\title{
Pengetahuan Siswa Ekstrakurikuler SMA Sederajat Kota Surakarta Tentang Pencegahan, Perawatan, Dan Pertolongan Pertama Cedera Olahraga
}

\author{
Nasri $^{1}$, Ari Sapti Mei Leni ${ }^{2}$ \\ ${ }^{1,2}$ Fakultas Ilmu Kesehatan, Universitas 'Aisyiyah Surakarta, Indonesia \\ E-mail: nasriow09@gmail.com ${ }^{1}$, salsabila_husna45@gmail.com²
}

Menerima: 30 Mei 2020; Revisi: 01,Oktober,2020; Diterima: 14,Oktober, 2020

https://doi.org/10.24036/MensSana.06012021.13

\begin{abstract}
Knowledge of sports injuries can be anticipated for students to perform and provide assistance to sports injuries quickly, appropriately, and can be applied to themselves and to others, so it is important to know the idea of student knowledge as the basis for conducting safe and injury-free sports activities. The purpose of this study is to find out the level of knowledge of students who participate in extracurricular sports activities on the prevention, treatment and first aid of sports injuries. This research was conducted in SMA, SMK, and MA in Surakarta City, with the condition that each school has a minimum of 3 extracurricular sports activities. The sample technique used in this study was purposive sampling, in order to obtain a total sample of 499 students from 35 high schools with pupulations 59 school. The questionnaire made in the form of google was given to the sample. The instruments used in this study consisted of (1) knowledge of sports injuries, (2) knowledge of sports injuries, and (3) knowledge of sports injury first aid. The results showed that students 'knowledge of prevention showed moderate category (68.1\%), students' knowledge of injuries showed moderate category (65.7\%), and student knowledge about first aid showed moderate category (64.7\%).
\end{abstract}

Keywords: knowledge, sports injury, first aid, sports extracurricular activities

\section{Abstrak}

Pengetahuan tentang cedera olahraga dapat menjadi antisipasi bagi siswa dalam melakukan dan memberikan pertolongan pada cedera olahraga dengan cepat, tepat, dan dapat diaplikasikan pada diri sendiri maupun kepada orang lain, sehingga penting dalam mengetahui gambaran tentang pengetahuan siswa sebagai dasar dalam melakukan kegiatan olahraga yang aman dan bebas cedera. Tujuan penelitian ini adalah mengetahui tingkat pengetahuan siswa yang mengikuti kegiatan ekstrakurikuler olahraga tentang pencegahan, perawatan dan pertolongan pertama cedera olahraga. Penelitian ini dilakukan di SMA, SMK, dan MA Negeri dan Swasta Kota Surakarta dengan syarat setiap sekolah mempunyai minimal 3 kegiatan ekstrakurikuler bidang olahraga. Teknik sampel yang digunakan pada penelitian ini adalah purposive sampling, sehingga diperoleh jumlah sampel sebanyak 499 siswa dari 35 sekolah menengah atas dengan populasi 59 sekolah. Kuesioner yang dibuat dalam bentuk google form yang diberikan kepada sampel. Instrumen yang digunakan pada penelitian ini terdiri dari (1) pengetahuan mengenai pencegahan cedera olahraga, (2) pengetahuan mengenai penanganan cedera olahraga, dan (3) pengetahuan mengenai pertolongan pertama cedera olahraga. Hasil penelitian menunjukkan bahwa pengetahuan siswa mengenai pencegahan cedera menunjukkan kategori sedang $(68,1 \%)$, pengetahuan siswa mengenai perawatan cedera menunjukkan kategori sedang $(65,7 \%)$, dan pengetahuan siswa mengenai pertolongan pertama cedera olahraga menunjukkan kategori sedang $(64,7 \%)$.

Kata Kunci: Pengetahuan, Pertolongan Pertama, Cedera Olahraga, Ekstrakurikuler Olahraga

\section{PENDAHULUAN}

Aktivitas fisik yang dilakukan tidak dapat dipungkiri akan ada resiko yang muncul bersandingan seiring aktivitas yang dilakukan, yaitu cedera. Cedera yang muncul dapat disebabkan oleh faktor internal dan faktor eksternal. Faktor internal merupakan faktor yang berasal dari individu sendiri, seperti koordinasi gerakan yang salah, beban berlebih, dehidrasi, dan lain-lain. Faktor eksternal yaitu faktor yang berasal dari luar individu atau lingkungan seperti cedera yang disebabkan karena kontak langsung, 


\section{Pengetahuan Siswa Ekstrakurikuler SMA Sederajat Kota Surakarta Tentang Pencegahan, Perawatan, Dan Pertolongan Pertama Cedera Olahraga \\ Nasri $^{1}$, Ari Sapti Mei Leni ${ }^{2}$}

sarana dan prasarana yang tidak aman, cuaca/lingkungan dan lain-lain (Arinda, 2014).

Pentingnya menciptakan rasa yang aman dalam proses belajar mengajar dan kegiatan ekstrakurikuler untuk meminimalisir hal-hal yang tidak diinginkan dapat dilakukan dengan cara mempersiapkan dan memeriksa sarana dan prasarana yang akan digunakan dalam proses pembelajaran atau kegiatan ekstrakulikuler. Menurut Afandi \& Alnedral, (2019) tingkat pengetahuan dan keterampilan siswa juga menjadi hal yang penting dalam pencegahan dan perawatan cedera serta penangan pertama cedera olahraga dalam proses kegiatan ekstrakulikuler agar dalam proses kegiatan tersebut dapat mengurangi/mencegah terjadinya cedera pada siswa. Pengetahuan tentang cedera olahraga dapat mengantispasi dan memberikan pertolongan ketika terjadi cedera dengan cepat dan tepat, serta dapat mencegah terjadinya cedera baik pada diri sendiri ataupun orang lain (Simatupang, 2016).

Cedera pada usia Sekolah Menengah Atas (SMA) sangat rentang terjadi salah satunya kurang sadar dan berhati-hati dalam melakukan aktivitas fisik. Beberapa aktivitas yang sering menjadi penyebab cedera pada anak-anak diantaranya bersepeda, bermain, berolahraga, serta aktivtias lainnya. Perlunya pembekalan ilmu oleh guru atau pembina ekstrakulikuler dengan ilmu pengetahuan serta keterampilan dalam pencegahan, pertolongan pertama dan perawatan cedera olahraga dalam proses pembelajaran siswa sehingga untuk meminimalisir terjadinya cedera pada siswa.

Pengetahuan tersebut dapat juga melalui pengalaman siswa, teman, dan orang tua. Beberapa penyebab cedera pada anak-anak yaitu 1) kurangnya kepekaan pada diri anak dalam menjaga keselamatan, sehingga kurang berhatihati, 2) bersikap masa bodoh dan tidak peduli disebabkan kurang bertanggungjawab dan antisipasi terhadap keselamatan diri sendiri, dan 3) kurang sikap disiplin (Suharto:2001 dalam Dimyati, 2018).

Kegiatan ekstrakurikuler olahraga dilakukan diluar jam tatap muka, yang dilaksanakan di dalam sekolah ataupun diluar sekolah dengan tujuan seperti yang tercantum dalam Permendikbud Republik Indonesia No. 62 Tahun 2014 tentang Kegiatan Ekstrakurikuler pada Tingkat Dasar dan Pendidikan Menengah pasal 2 menyebutkan bahwa kegiatan ekstrakurikuler diselenggarakan dengan tujuan untuk mengembangkan potensi, bakat, minat, kemampuan, kepribadian, kerjasama, dan kemandirian peserta didik secara optimal dalam rangka mendukung pencapaian tujuan pendidikan nasional. Kegiatan ekstrakurikuler olahraga sudah mulai diajarkan pada tingkat sekolah tingkat bawah sampai sekolah tinggi atas.

Menurut Direktorat Pendidikan Menengah Kejuruan (Surobroto 2019 dalam Saputra, 2017) tujuan pelaksanaan ekstrakurikuler pada sekolah yaitu 1) kegiatan ekstrakurikuler harus meningkatkan kemampuan siswa dalam aspek kognitif, afektif, dan psikomotor, 2) mengembangkan bakat dan minat peserta didik pada upaya pembinaan pribadi menuju pembinaan manusia seutuhnya yang positif, 3) dapat mengetahui, mengenal dan membedakan antara korelasi satu pelajaran dengan pelajaran lainnya.

Ekstrakulikuler bidang olahraga merupakan salah satu faktor penunjang dalam pembiasaan yang positif bagi peserta didik dan pula menjadi kebanggaan bagi sekolah. Di era saat ini aktivitas olahraga telah menjadi sorotan di berbagai negara, hal ini merupakan salah satu bentuk perjuangan dan mengharumkan bangsa dan negara. Dukungan pemerintah dalam mengakomodir terlihat dengan adanya kejuarankejuaran yang dilaksanakan setiap tahunnya seperti O2SN (Olimpiade Olahraga Siswa Nasional) pada jenjang Sekolah Dasar, Sekolah Menengan Pertama, dan Sekolah Menengah Atas, POMNas (Pekan Olahraga Mahasiswa Nasional) pada jenjang perguruan tinggi.

Kegiatan dan kompetisi olahraga seperti O2SN dan POMNas menjadi cikal bakal lahirnya atlet profesional di tingkat nasional, sehingga dukungan besar tentu diberikan oleh pihak sekolah dalam mempersiapkan ajang tahunan tersebut. Ekstrakurikuler olahraga menjadi wadah bagi siswa-siswa di sekolah dalam menyalurkan minat dan bakat serta mempersiakan kompetisi olahraga pada tingkat kabupaten, provinsi dan nasional. Diharapkan keikutsertaan peserta didik mengikuti kegiatan ektrakurikuler dapat mengembangkan fisik, mental, dan emosional peserta didik secara optimal (Saputra, 2017).

Menurut Notoatmodjo dalam Hastuti (2017) menjelaskan bahwa pengetahuan berperan dalam pembentukan sikap seseorang, pengetahuan membuat seseorang berfikir akan suatu objek atau stimulus. Pengetahuan yang dimiliki seseorang dapat dipengaruhi oleh faktor 
internal dan eksternal. Faktor internal meliputi keadaan jasmani dan keadaan rohani seseorang (kesehatan psikis, psikomotor, intelektual, kognitif dan afektif), sedangkan faktor eksternal meliputi pendidikan, paparan media massa, keadaan ekonomi, dan hubungan sosial media (Wawan \& Dewi, 2011)

Faktor-faktor yang mempengaruhi terbentuknya pengetahuan yaitu 1) pendidikan, 2) informasi/media massa, 3) sosial, budaya, dan ekonomi, 4) lingkungan, 5) pengalaman, dan usia (Simatupang, 2016). Semakin tinggi tingkat pendidikan seseoorang maka akan semakin mudah menerima informasi sehingga banyak pula pengetahuan yang dimiliki (Triyani \& Ramdani, 2020). Dengan adanya informasi yang baru mengenai berbagai hal maka dapat memberikan landasan kognitif baru yang pada akhirnya terbentuknya pengetahuan terhadap hal tersebut.

Menurut Budiman (2013) dalam Simatupang (2016), jenis pengetahuan dibagi menjadi dua yaitu pengetahuan implist dan pengetahuan eksplisit. pengetahuan implisit merupakan pengetahuan yang masih tertanam dalam bentuk pengalaman seseorang dan berisi faktor-faktor yang tidak bersifat nyata, seperti keyakinan pribadi, perspektif dan prinsip. sedangkan pengethuan eksplisit meruapakan pengetahuan yang telah disimpan dalam wujud nyata, bisa dalam wujud perilaku kesehatan.

Menurut Khadavi \& Ulfah, (2019) bahwa cedera atau trauma itu adalah segala sesuatu yang berbentuk peristiwa yang telah terjadi, yang mengenai jaringan tubuh secara tiba-tiba. Hal yang sama dikemukakan WHO (2008) \& WHO (2014) dalam Lubis et al., (2015) bahwa cedera sendiri merupakan kerusakan fisik yang terjadi ketika tubuh manusia tiba-tiba mengalami penurunan energi dalam jumlah yang melebihi ambang batas toleransi fisiologis atau akibat dari kurangnya satu atau lebih elemen penting seperti oksigen.

Menurut Wijaya et al., (2019) fenomena yang terjadi di Indonesia menujukkan kejadian cedera olahraga masih tinggi terjadi di sekolah, seperti luka, memar, keseleo, kram, patah tulang, dan lain-lain. Diperkirakan 10-25\% dari cedera yang terjadi pada anak-anak terjadi saat mereka berada di sekolah, beberapa cedera terjadi secara tidak sengaja setiap tahunnya (Sepien dalam AlYahya et al., 2019). Orang dewasa lebih kecil kemungkinan menderita cedera olahraga daripada anak-anak, rentang akan terjadi cedera meningkat dikarenakan refleks yang belum matang, kemampuan untuk mengenali dan mengevaluasi risiko dan koordinasi yang kurang berkembang (Elmagd, 2016)

Usaha dalam mencegah terjadinya cedera olahraga dapat dilakukan pada saat sebelum latihan, saat latihan, dan sesudah latihan. Pencegahan setara dengan usaha untuk menahan, mengurangi, atau menghentikan dampak dan akibat terjadinya risiko yang akan terjadi. Dalam kegiatan olahraga perlu dibekali pengetahuan tentang cedera olahraga berupa cara pencegahan cedera, penyebab terjadinya cedera dan keterampilan dalam penanganan cedera olahraga pada saat di lapangan (Sari \& Purnawan, 2017:53). Melakukan pemanasan yang cukup menjadi salah satu cara paling bijak untuk menghindari cedera ringan. Selain itu, melakukan recovery tubuh dapat mencegah terjadinya cedera dengan cara meningkatkan metabolism tubuh. (Mukrim et al., 2017)

Cedera dapat terjadi pada bagian tubuh diantaranya kulit berupa lecet, terkelupas, terpotong maupun luka tusuk, cedera pada kepala berupa geger otak, cedera panas, cedera pada ligamen (sprain), dan cedera pada otot/tendon (strain) dan yang terjadi di bagian tubuh atas dan bawah, cedera patah tulang (fraktur) dan cedera pada sendi. Tingkat cedera dibagi menjadi tiga tingkat yaitu 1) derajat 1 berupa robekan ringan yang mengenai beberapa serabut dari otot/tendon atau ligamen, 2) derajat 2 berupa robekan Sebagian pada otot/tendon atau ligament, dan 3) derajat 3 berupa robekan total atau terputusnya otot/tendon atau ligament.

Menurut Mustofa (2017), pencegahan cedera dapat dilakukan melalui keterampilan, pemanasan, pendinginan, makanan/nutrisi, latihan yang benar dan sarana prasarana latihan. Keterampilan seorang atlet harus diperhatikan dalam pemberian jenis latihan dan dosis latihan, hal ini akan membantu dalam mencegah terjadinya cedera. Pemanasan dan pendinginan yang bagus akan menghindari dari cedera olahraga (Walker, 2013).

Menurut Elmagd (2016), cedera olahraga dapat diakibatkan karena kecelakaan, melakukan teknik olahraga yang buruk, perlengkapan yang tidak memadai, dan penggunaan berlebihan (overuse). Faktor penyebab dari cedera olahraga adalah faktor olahragawan (dari dalam) dan faktor peralatan dan fasilitas (dari luar) 


\section{Pengetahuan Siswa Ekstrakurikuler SMA Sederajat Kota Surakarta Tentang Pencegahan, Perawatan, Dan Pertolongan Pertama Cedera Olahraga \\ Nasri $^{1}$, Ari Sapti Mei Leni ${ }^{2}$}

(Afriwardi, 2011). Faktor olahragawan meliputi umur, pengalaman, teknik, kematangan, pengalaman, tingkat latihan, pemanasan, recovery period, kebugaran, istirahat, dan keseimbangan nutrisi. Faktor peralatan dan fasilitas meliputi sarana prasaran yang kurang memadai, alat-alat proteksi badan, dan karakteristik dari olahraga (Meikahani \& Kriswanto, 2015)

Ketika terjadi cedera olahraga upaya rehabilitasi medik perlu dilakukan, penanganan pertama cedera. Cedera akut terjadi dalam kurung waktu 0 - 24 jam, hal yang harus diperhatikan yaitu evaluasi tentang keadaan umum penderita, hal ini guna menentukan apakah ada keadaan yang akan mengancam hidup penderita. Perawatan (penanganan) cedera olahraga mencakup penanganan melalui layanan rehabilitasi medik, layanan fisioterapi, layanan alat bantu/ortesa dan layanan penganti tubuh/protesa (Meikahani \& Kriswanto, 2015).

Manajemen akut (soft tissue injury) cedera olahraga pada luka memar pertolongan pertama cedera olahraga pada luka memar dapat dikompres dengan air es atau air dingin dan berikan balutan untuk penekanan. Pembengkakan karena memar kadang-kadang dapat menggunakan salep. Mengatasi kram otot dapat dilakukan pertolongan pertama yaitu kontraksikan otot yang berlawanan, melakukan perengangan secara bertahap dari otot yang terkena, dan melakukan massage dengan gerakan menurut dengan lebut kearah jantung.

Manajemen akut (soft tissue injury) cedera olahraga pada jaringan lunak dapat ditangani dengan metode PRICES (Protection, Rest, Ice, Compression, Elevation, Support) biasanya pada kasus sprain dan strain. Metode PRICES tidak boleh dilakukan pada kasus cedera olahraga seperti kram otot, , luka terbuka pada kulit, dan patah tulang terbuka serta memiliki alergi dingin.

Menurut Bahruddin (2013:5) pertolongan pertama meliputi seluruh persiapan dan tindakan dalam memberikan perawatan darurat ketika terjadi cedera secara tiba-tiba. Saat dihadapkan dengan situasi seperti itu, tidak selalu menjadi pekerjaan oleh tim medis, karena setiap individu dalam melakukan intervensi pertolongan pertama pada diri sendiri ataupun pada orang lain (Barutcu et al., 2017).

Kegiatan ekstrakurikuler olahraga di sekolah dapat menjadi sebuah pijakan bagi siswa untuk mengembangkan minat, hobi dan prestasinya. Ketika siswa melakukan kegiatan olahraga saat berlatih atau berkompetisi ada potensi cedera olahraga dapat terjadi, sehingga penting bagi siswa untuk dapat memahami dan mengetahui mengenai cedera olahraga. Oleh karena itu, diperlukan adanya penelitian yang bertujuan mengetahuai tingkat pengetahuan siswa mengenai pencegahan, perawatan dan pertolongan pertama cedera olahraga.

Tujuan dari penelitian ini yaitu mengetahui tingkat pengetahuan siswa yang bergabung dalam kegiatan ekstrakurikuler bidang olahraga pada Sekolah Menengah Atas sederajat di Kota Surakarta mengenai pencegahan cedera olahraga, perawatan cedera olahraga dan pertolongan pertama pada cedera olahraga. Hal ini juga dapat menjadi pertimbangan bagi sekolah, dinas Pendidikan, dan pihak terkait dalam mengambil keputusan terkait kesehatan dan keselamatan siswa.

Berdasarkan penjelasan di atas, penting untuk mengetahui tingkat pengetahuan siswa yang bergabung dalam kegiatan ekstrakurikuler olahraga sehingga dapat memberikan gambaran tentang tingkat pengetahuan siswa terkait pencegahan cedera olahraga, perawatan cedera olahraga dan pertolongan pertama pada cedera olahraga pada siswa SMA Sederajat yang mengikuti ekstrakurikuler bidang olahraga.

\section{METODE}

Penelitian ini adalah penelitian deskriptif, yaitu memaparkan atau menggambarkan keadaan objek atau peristiwa yang diteliti. Penelitian dilaksanakan pada bulan Juni hingga September 2020 di SMA, SMK dan MA se Kota Surakarta yang memenuhi kriteria. Subjek dalam penelitian ini merupakan seluruh siswa yang mengikuti kegiatan ekstrakurikuler bidang olahraga.

Penelitian ini dilakukan di SMA, SMK, dan MA Negeri dan Swasta Kota Surakarta dengan syarat setiap sekolah mempunyai minimal 3 kegiatan ekstrakurikuler bidang olahraga. Populasi dalam penelitian ini sebanyak 59 sekolah yang memiliki ekstrakurikuler bidang olahraga. Teknik sampel yang digunakan pada penelitian ini adalah purposive sampling, sehingga diperoleh jumlah sampel sebanyak 499 siswa dari 35 sekolah menengah atas.

Peneliti menggunakan teknik analisis data kuantitatif dengan pendekatan deskriptif. Menggunakan perhitungan untuk membantu dalam pengolahan data, yaitu dengan cara menghitung skor dari masing-masing jawaban dari lembar soal tes yang telah dikerjakan oleh siswa. Dari hasil perhitungannya ditunjukkan dengan pengkategorian skor. Pengkategorian 
skor menggunakan penyusunan urutan kedudukan atas tiga rangking. Adapun patokan yang digunakan yaitu 1) kategori tinggi yaitu semua responden yang mempunyai skor sebanyak skor rata-rata plus $1(+1)$ standar deviasi ( $\mathrm{X}>\mathrm{Mi}+1 \mathrm{SDi}) ; 2)$ kategori sedang yaitu semua responden yang mempunyai skor antara skor rata-rata minus 1 standar deviasi dan skor rata-rata plus 1 standar deviasi (antara $\{(\mathrm{Mi}-1$ $\mathrm{SDi} \leq \mathrm{X}<(\mathrm{Mi}+\mathrm{SDi})\})$; 3) kategori kurang yaitu semua responden yang mempunyai skor lebih rendah dari skor rata-rata minus 1 standar deviasi $(\mathrm{X}<\mathrm{Mi}-1 \mathrm{SDi}$ ) (Arikunto, 2011)

Teknik pengambilan data menggunakan kuesioner berupa pilihan ganda yang sudah dilakukan uji validitas dan reliabilitas. Kuesioner yang dibuat dalam bentuk google form yang diberikan kepada sampel. Instrumen yang digunakan pada penelitian ini terdiri dari (1) pengetahuan mengenai pencegahan cedera olahraga, (2) pengetahuan mengenai penanganan cedera olahraga, dan (3) pengetahuan mengenai pertolongan pertama cedera olahraga (Mustofa, 2017).

Variabel pencegahan cedera mencakup pengetahuan pencegahan cedera olahraga melalui keterampilan, pengetahuan pencegahan melalui melakukan pemanasan dan pendinginan, pengetahuan pencegahan melalui makanan/nutrisi, pengetahuan pencegahan melalui latihan, pengetahuan pencegahan melalui peralatan dan lingkungan, pengetahuan pencegahan cedera lewat pakaian.

Untuk variabel perawatan (penanganan) cedera olahraga mencakup pengetahuan pertolongan pendarahan, pengetahuan pertolongan pertama, pengetahuan, pengetahuan perawatan cedera melalui pelayanan fisioterapi, pengetahuan perawatan cedera melalui pelayanan alat bantu (ortesa), pengetahuan perawatan cedera melalui pelayanan pengganti tubuh (protesa). Untuk variabel pertolongan pertama cedera olahraga mencakup pengetahuan pertolongan pertama cedera olahraga pada cedera memar, strain dan sprain melalui metode PRICES, pengetahuan pertolongan pertama cedera olahraga pada cedera lepuh, pingsan, pendarahan, kram otot, dislokasi, dan patah tulang (fractur).

\section{HASIL DAN PEMBAHASAN}

Penelitian ini dilakukan di SMA, SMK, dan MA Negeri dan Swasta Kota Surakarta dengan syarat setiap sekolah mempunyai minimal 3 kegiatan ekstrakurikuler bidang olahraga. Teknik pengambilan sampel menggunakan purposive sampling, sehingga diperoleh sampel sebanyak 499 siswa dari 35 sekolah menengah atas.

Tabel 1. Distribusi Frekuensi Siswa yang Mengikuti Ektrakurikuler Olahraga Berdasarkan

\begin{tabular}{cccc}
\multicolumn{4}{c}{ Umur } \\
\hline No. & $\begin{array}{c}\text { Klasifikasi } \\
\text { Umur }\end{array}$ & $\begin{array}{c}\text { Frekuensi } \\
\text { (f) }\end{array}$ & $\begin{array}{c}\text { Persentase } \\
(\mathbf{\%})\end{array}$ \\
\hline 1 & 14 Tahun & 5 & 1 \\
2 & 15 tahun & 155 & 31 \\
3 & 16 Tahun & 184 & 37 \\
4 & 17 Tahun & 116 & 23 \\
5 & 18 Tahun & 30 & 6 \\
6 & 19 Tahun & 8 & 2 \\
& Jumlah & $\mathbf{4 9 9}$ & $\mathbf{1 0 0 \%}$ \\
\hline
\end{tabular}

Berdasarkan tabel 1 diketahui umur dari responden dalam penelitian yaitu umur 14 tahun sebanyak 5 orang (1\%), umur 15 tahun sebanyak 155 orang $(31 \%)$, umur 16 tahun 184 orang (37\%), umur 17 tahun sebanyak 116 orang $(23 \%)$, umur 18 tahun sebanyak 6 orang $(6 \%)$, dan umur 19 tahun sebanyak 8 orang $(2 \%)$. Sehingga dengan melihat tabel 1 dapat disimpulkan bahwa mayoritas responden berusia 16 tahun yaitu 184 orang (37\%) dan yang paling sedikit berusia 14 tahun yaitu sebanyak 5 orang (1\%).

Tabel 2. Distribusi Frekuensi Siswa yang Mengikuti Ektrakurikuler Olahraga Berdasarkan Jenis Kelamin

\begin{tabular}{cccc}
\hline No. & $\begin{array}{c}\text { Jenis } \\
\text { Kelamin }\end{array}$ & $\begin{array}{c}\text { Frekuensi } \\
\text { (f) }\end{array}$ & $\begin{array}{c}\text { Persentase } \\
\text { (\%) }\end{array}$ \\
\hline 1 & Laki-laki & 246 & 49,3 \\
2 & Perempuan & 253 & 50,7 \\
& Jumlah & $\mathbf{4 9 9}$ & $\mathbf{1 0 0 \%}$ \\
\hline
\end{tabular}

Dari tabel 2 menjukkan bahwa responden yang mengikuti penelitian didominasi oleh perempuan sebanyak 253 orang $(50,7 \%)$, dan laki-laki sebanyak 246 orang $(49,3 \%)$.

Tabel 3. Distribusi Frekuensi Siswa Berdasarkan

Pengetahuan tentang Pencegahan Cedera Olahraga

\begin{tabular}{cccc}
\hline No. & Kategori & $\begin{array}{c}\text { Frekuensi } \\
\text { (f) }\end{array}$ & $\begin{array}{c}\text { Persentase } \\
(\mathbf{\%})\end{array}$ \\
\hline 1 & Tinggi & 98 & 19,6 \\
2 & Cukup & 340 & 68,1 \\
3 & Kurang & 61 & 12,2 \\
& Jumlah & $\mathbf{4 9 9}$ & $\mathbf{1 0 0 \%}$ \\
\hline
\end{tabular}

Dari tabel 3 menunjukkan hasil bahwa tingkat pengetahuan siswa yang mengikuti 


\section{Pengetahuan Siswa Ekstrakurikuler SMA Sederajat Kota Surakarta Tentang Pencegahan, Perawatan, Dan Pertolongan Pertama Cedera Olahraga \\ Nasri $^{1}$, Ari Sapti Mei Leni ${ }^{2}$}

ekstrakurikuler olahraga mengenai pencegahan cedera olahraga sebanyak 98 orang $(19,6 \%)$ pada kategori tinggi. Pada kategori cukup sebanyak 340 orang $(68,1 \%)$, dan kategori kurang sebanyak 61 orang $(12,2 \%)$. Sehingga dapat disimpulkan bahwa tingkat pengetahuan siswa mengenai pencegahan cedera termasuk kategori sedang.

Tabel 4. Distribusi Frekuensi Siswa Berdasarkan Pengetahuan tentang Perawatan Cedera Olahraga

\begin{tabular}{clcc}
\hline No. & Kategori & $\begin{array}{c}\text { Frekuensi } \\
\text { (f) }\end{array}$ & $\begin{array}{c}\text { Persentase } \\
\text { (\%) }\end{array}$ \\
\hline 1 & Tinggi & 59 & 11,8 \\
2 & Cukup & 328 & 65,7 \\
3 & Kurang & 112 & 22,4 \\
& Jumlah & $\mathbf{4 9 9}$ & $\mathbf{1 0 0 \%}$ \\
\hline
\end{tabular}

Dari tabel 4 menunjukkan hasil bahwa tingkat pengetahuan siswa yang mengikuti ekstrakurikuler olahraga mengenai perawatan cedera olahraga sebanyak 98 orang $(19,6 \%)$ pada kategori tinggi. Pada kategori cukup sebanyak 340 orang $(68,1 \%)$, dan kategori kurang sebanyak 61 orang $(12,2 \%)$. Sehingga dapat disimpulkan bahwa tingkat pengetahuan siswa mengenai perawatan cedera termasuk kategori sedang.

Tabel 5. Distribusi Frekuensi Siswa Berdasarkan Pengetahuan tentang Pertolongan Pertama Cedera Olahraga

\begin{tabular}{cccc}
\hline No. & Kategori & $\begin{array}{c}\text { Frekuensi } \\
\text { (f) }\end{array}$ & $\begin{array}{c}\text { Persentase } \\
\text { (\%) }\end{array}$ \\
\hline 1 & Tinggi & 89 & 17,8 \\
2 & Cukup & 323 & 64,7 \\
3 & Kurang & 87 & 17,8 \\
& Jumlah & $\mathbf{4 9 9}$ & $\mathbf{1 0 0 \%}$ \\
\hline
\end{tabular}

Dari tabel 5 menunjukkan hasil bahwa tingkat pengetahuan siswa yang mengikuti ekstrakurikuler olahraga mengenai pertolongan pertama cedera olahraga yaitu sebanyak 89 orang $(17,8 \%)$ pada kategori tinggi, kategori cukup sebanyak 323 orang $(64,7 \%)$, dan kategori kurang sebanyak 87 orang $(17,8 \%)$. Sehingga dapat disimpulkan bahwa tingkat pengetahuan siswa mengenai pertolongan pertama cedera olahraga termasuk kategori sedang. Untuk lebih jelasnya dapat dilihat pada gambar di bawah ini:

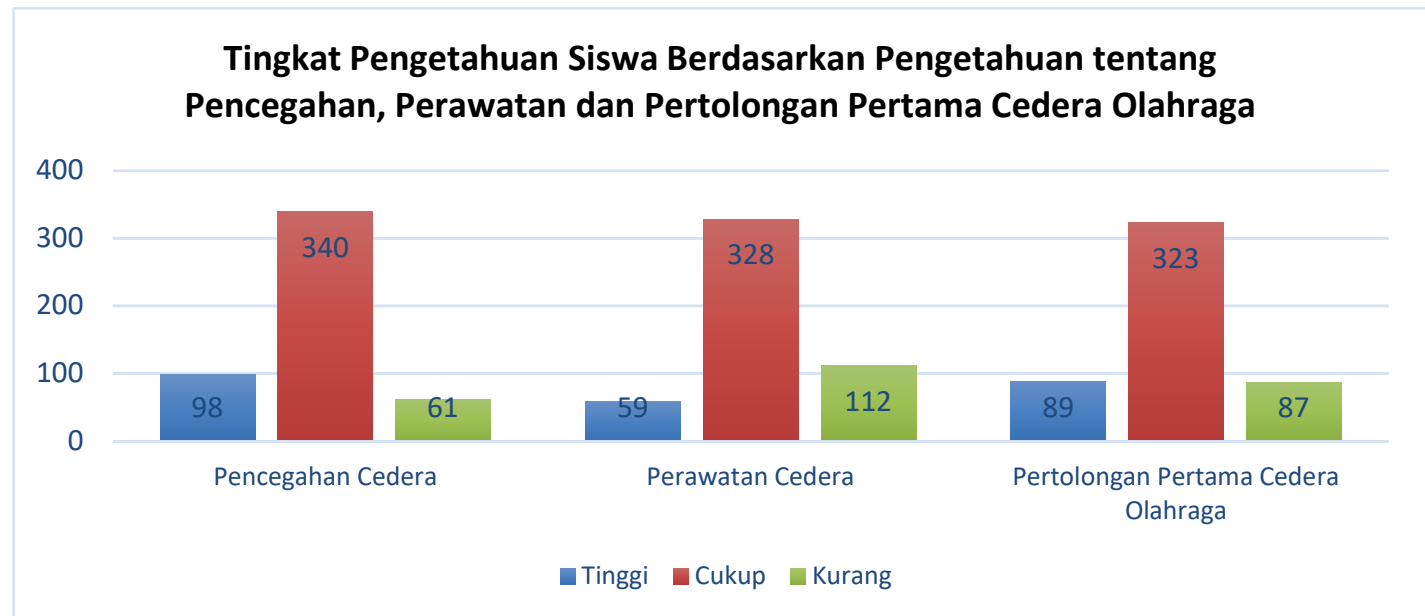

Gambar 1. Tingkat Pengetahuan Siswa Berdasarkan Pengetahuan tentang Pencegahan, Perawatan dan Pertolongan Pertama Cedera Olahraga

Pembahasan

Penelitian ini memiliki tujuan untuk mengetahui tingkat pengetahuan siswa yang ikut ekstrakurikuler bidang olahraga mengenai pencegahan cedera olahraga, perawatan cedera olahraga, dan pertolongan pertama pada cedera olahraga pada tingkat Sekolah Menengah Atas sederajat Kota Surakarta.

Penelitian dilaksanakan pada bulan Juli hingga September 2020 di SMA sederajat Kota Surakarta mengenai pengetahuan siswa ekstrakurikuler SMA sederajat tentang pencegahan cedera olahraga, perawatan cedera olahraga dan pertolongan pertama pada cedera olahraga dapat kita ketahui bahwa mayoritas pengetahuan siswa mengenai pencegahan, perawatan dan pertolongan pertama cedera olahraga pada kategori sedang.

Menurut (Wulandini et al., 2019) yang mempengaruhi tingkat pengetahuan siswa mengenai pertolongan pertama pada kecelakaan ketika berolahraga diantaranya faktor usia, faktor pendidikan, dan faktor sumber informasi. Usia adalah rentang waktu seseorang yang dihitung sejak dia dilahirkan. Bertambahnya usia maka daya tangkap dan pola pikir juga juga 
berkembang sehingga pengetahuan yang didapatkan juga akan semakin membaik (Simatupang, 2016)

Perbedaan tingkat pengetahuan siswa dapat dilihat dari latar belakang penerimaan informasi yang diterima, lingkungan sekolah atau lingkungan keluarga dan tempat tinggal, lingkungan teman sebaya serta pengalaman yang dimiliki dan juga informasi dari media sosial (Afandi \& Alnedral, 2019).

Hasil penelitian yang dilakukan menunjukkan bahwa pengetahuan siswa mengenai pencegahan cedera menunjukkan kategori sedang $(68,1 \%)$, hal tersebut ditunjukkan pada tabel 3 diatas. Cedera olahraga dapat terjadi dimana saja, baik ketika berlatih ataupun saat mengikuti kompetisi, bahkan tidak menutup kemungkinan dapat terjadi pada setiap siswa yang mengikuti kegiatan olahraga. Setiap siswa mempunyai tanggung jawab dalam menjaga dan mencegah terjadinya cedera kepada diri sendiri, sehingga perlunya pemahaman yang tinggi dimiliki kepada setiap siswa terutama yang mengikuti kegiatan ekstrakurikuler.

Pemahaman dibutuhkan agar siswa mampu melakukan tindakan pencegahan cedera olahraga, dengan adanya pemahaman tentang cedera, keterampilan, pentingnya pemanasan dan pendinginan, makanan serta sarana prasarana yang baik maka siswa dapat memberikan tindakan preventif sebelum melakukan aktivitas olahraga. Latihan-latihan tersebut dapat dilakukan untuk mencegah terjadinya cedera ketika latihan atau ketika bertanding (Fadilah dan Rahil, 2019).

Menurut Rössler et al., (2018), pelaksanaan program pencegahan cedera diperlukan untuk mencegah terjadinya cedera dalam berolahraga pada anak-anak. Penelitian sebelumnya mengungkapkan bahwa pencegahan cedera berbasis pengprograman latihan dapat mengakibatkan penurunan cedera sekitar $46 \%$ dalam olahraga pada usia remaja (Rössler et al., 2014).

Menurut Ismunandar (2020), tindakantindakan intervensi dan pencegahan dapat meminimalkan terjadinya cedera, mengurangi biaya perawatan, meningkatkan kesejahteraan anak, dan memastikan kelangsungan partisipasi anak dalam kegiatan olahraga. Terdapat berbagai cara dalam meminimalisis dan mencegah cedera pada atlet muda yaitu 1) menjaga kesehatan dan kebugaran, 2) menyediakan periode waktu untuk mengurangi latihan dan beban pada saat atlet memasuki usia tumbuh kembang, 3) edukasi, 4) latihan untuk memperkuat bagian pinggul, 5) pola tidur sehat, 6) latihan multilateral, 7) perlengkapan latihan yang sesuai, 8) berhenti dan perawatan ketika cedera, 9) edukasi untuk penanganan cedera, dan 10) selalu menjaga sportifitas dalam berolahraga (Stracciolini et al., 2017)

Menurut Bompa (2000) dalam Dimyati (2018: 2) penyebab terjadinya cedera pada anakanak ketika berolahraga yaitu lemahnya otot perut, pengetahuan tentang latihan dan penambahan beban kurang, serta sikap tubuh yang salah ketika mengangkat beban. Dari hal tersebut terlihat jelas bahwa penting bagi pelaku olahraga untuk memahami hal-hal yang dapat mencegah terjadinya cedera olahraga.

Hasil penelitian yang telah dilakukan menggambarkan bahwa pengetahuan siswa mengenai perawatan cedera menunjukkan kategori sedang $(65,7 \%)$, dapat dilihat pada tabel 4 diatas. Hasil ini dapat diartikan bahwa siswa mengetahui perawatan cedera. Siswa memahami bahwa ketika cedera dapat dilakukan tindakantindakan perawatan dengan berbagai jenis cedera, alat-alat bantu yang dapat membantu dalam proses rehabilitasi cedera olahraga.

Hal berbeda ditunjukkan pada penelitian Hardyanto \& Nirmalasari, (2020) mengenai tingkat pengetahuan mahasiswa UKM olahraga pada kategori baik (79,7\%). Hal yang menyebabkan bisa karena tingkat pendidikan setiap sampel. Tingkat pendidikan yang lebih tinggi akan lebih mudah dalam menerima segala informasi yang ada (Triyani \& Ramdani, 2020).

Penanganan cedera terdapat berbagai cara yang bisa dilakukan antara lain menggunakan pengobatan medis juga non medis, pengobatan medis mencakup terapi rehabilitasi olahraga menggunakan pengobatan alternatif dan olahraga terapi menjadi pilihan buat penyembuhan pasca cedera yang dialami oleh seorang atlet. Terapi yang dapat digunakan dapat berupa terapi herbal, terapi massage, terapi yoga, exercise therapy, thermotherapy, coldtherapy, hydrotherapy, manual theraphy, dan lain-lain (Sa'roni \& Graha, 2019).

Penanganan dan perawatan cedera perlu diketahui terlebih dahulu cedera yang dialami dan apa langkah yang harus dikerjakan. 


\section{Pengetahuan Siswa Ekstrakurikuler SMA Sederajat Kota Surakarta Tentang Pencegahan, Perawatan, Dan Pertolongan Pertama Cedera Olahraga \\ Nasri $^{1}$, Ari Sapti Mei Leni ${ }^{2}$}

Penangan cedera dengan pelayanan spesialistik rehabilitas medik. Proses rehabilitasi pada cedera akut berlangsung 0 hingga 24 jam, yang merupakan hal paling penting ketika penanganan dan perawatan pertama yaitu melakukan evaluasi awal mengenai kondisi umum pasien, serta memastikan apakah ada sesuatu yang membahayakan jiwanya.

Penanganan dan perawatan cedera fase kronik dapat diberikan berupa kompres dingin, massage es, rendalaman air dingin, semprotan dingin, terapi panas, ultrasound, infrared. Selain itu fase rehabilitasi juga dapat diberikan hydroterapi, massage, terapi latihan. Pemberian alat bantu juga bisa diberikan ketika terjadi cedera akut, biasanya untuk mengistirahatkan bagian tubuh yang cedera, dengan harapan dapat membantu dalam proses mempercepat penyembuhan dan juga melindungi dari cedera berulang.

Hasil penelitian yang dilakukan menunjukkan bahwa pengetahuan siswa mengenai pertolongan pertama cedera olahraga menunjukkan kategori sedang $(64,7 \%)$, dapat dilihat pada tabel 5. Hal tersebut menunjukkan bahwa siswa mengetahui pertolongan pertama yang dapat diberikan ketika terjadi cedera olahraga, sehingga dapat mencegah cedera yang lebih parah.

Hasil penelitian yang sama ditunjukkan oleh (Wulandini et al., 2019) di SMA Olahraga Rumbai Pekanbaru bahwa sekitar 86,25\% pengetahuan siswa mengenai pengetahuan pertolongan pertama cedera olahraga pada ketegori cukup, lebih lanjut disampaikan bahwa informasi yang didapatkan banyak berasal dari tenaga Kesehatan.

Meskipun hasil penelitian menujukkan tingkat pengetahuan mengenai pertolongan pertama pada kategori sedang, namun dengan adanya siswa yang salah dalam memberikan pertolongan pertama tidak dapat dibiarkan begitu saja terjadi. Oleh sebab itu, tidak boleh diabaikan bahwa dalam pemberian pertolongan pertama, pemberian pertolongan yang salah dapat mengakibatkan kematian atau kecatatan pasien (Barutcu et al., 2017:1567)

Menurut Baser (2007) dalam Mobarak et al., (2015) pengetahuan tentang langkah-langkah dalam pertolongan pertama penting bagi setiap individu di setiap usia, termasuk anak-anak sekolah. Perlunya lingkungan pendidikan di sekolah menfasilitasi pengajaran dan pelatihan dalam berbagai topik seperti pertolongan pertama. Oleh karena itu, banyak penelitian menekankan bahwa mengajar dasar-dasar pertolongan pertama wajib di semua sekolah (Afifi et al., 2015)

Prinsip penanganan cedera olahraga dengan meode PRICES memiliki tujuan untuk mengurangi peradangan yang terjadi sesaat setelah terjadi cedera juga dapat mencegah risiko yang lebih memperparah cedera, serta merupakan Tindakan penanganan cedera olahraga yang cukup mudah untuk diaplikasikan. Penanganan cedera olahraga dengan metode PRICES bertujuan untuk membantu penyembuhan cedera antara lain sebagai berikut: 1) mengurangi terjadinya pendarahan, dimana dengan pemberian kompres es akan terjadi vasikontriksi dari pembuluh darah pada area yang cedera, 2) untuk mengurangi rasa nyeri pada area cedera karena dapat menghilangkan rasa nyeri dengan pemberian kompres es, 3) mengurangi gerakan yang dilakukan (imobilisasi), 4) cukup efektif untuk penyembuhan cedera karena pemberian tindakan dapat mengurangi peradangan (inflamasi) yang terjadi akibat cedera (Okta \& Hartono, 2020:107).

Penerapan pemahaman terhadap pencegahan cedera olahraga, perawatan cedera olahraga, dan pertolongan pertama pada cedera olahraga akan membantu siswa dalam mencegah cedera selama mengikuti kegiatan ekstrakurikuler. Pemberian pengetahuan tentang manajemen cedera dan penyakit secara benar kepada siswa merupakan model yang masuk akal dan logis (Shinde, 2015).

Dalam beberapa informasi pertolongan pertama cedera olahraga dasar, siswa mungkin dapat salah dalam menerima informasi. Oleh sebab itu, penting bagi siswa dalam pemberian pelatihan terkait dengan hal itu sehingga kedepannya dapat diperbaiki. Hal tersebut dapat menjadi acuan untuk kepada instansi terkait melakukan pelatihan atau penyuluhan atau dimasukkan kedalam mata pelajaran untuk meningkatkan kompetensi khusus terkait dengan pertolongan pertama.

\section{KESIMPULAN}

Dari hasil penelitian yang telah peneliti lakukan mengenai pengetahuan siswa ekstrakurikuler olahraga SMA sederajat tentang pencegahan, perawatan cedera dan pertolongan pertama cedera olahraga, maka dapat disimpulkan bahwa pengetahuan siswa ektrakurikuler mengenai pencegahan cedera 
adalah dengan kategori sedang, pengetahuan siswa ektrakurikuler mengenai perawatan cedera adalah dengan kategori sedang, dan tingkat pengetahuan siswa ektrakurikuler mengenai pertolongan pertama cedera adalah dengan kategori sedang.

Batasan dalam penelitian ini pada proses pengumpulan data di lapangan, dengan kondisi pandemi akibat adanya Covid-19 menyebabkan proses belajar mengajar di sekolah terganggu, siswa melakukan proses belajar di rumah masingmasing. Hal ini juga berakibat pada proses kegiatan ekstrakurikuler yang tidak dapat berjalan,

Hasil penelitian ini dapat menjadi sebuah perhatian serius bagi sekolah-sekolah, pembinan ekstrakurikuler dan khususnya kepada instansi terkait dalam menjaga keselamatan dan kesehatan kepada seluruh siswa yang mengikuti kegiatan ekstrakurikuler bidang olahraga dalam meningkatkan pengetahuan dan pemahaman mengenai pencegahan, perawatan dan pertolongan pertama cedera olahraga pada level yang tinggi. Harapanya dengan informasi tersebut, pihak terkait dapat melakukan pemberian penyuluhan dan pelatihan kepada seluruh siswa.

\section{DAFTAR PUSTAKA}

Afandi, I., \& Alnedral. (2019). Tingkat Pengetahuan Siswa Tentang Pentingnya Pemanasan Dan Pendinginan Pada Sekolah Sepak Bola (SSB) Tunas Harapan Kecamatan Lubuk Basung Kabupaten Agam. Jurnal Patriot, 1(1), 249-256.

Afifi, R. M., Zaytou, S. S., El Raggal, A. A., Qulali, A., \& Ayoub, H. A. K. (2015). Involvement of Male Youth into Accidents in Upper Egypt: Pattern and Risk Analysis. Health, 07(08), 965-975.

Afriwardi. (2011). Ilmu Kedokteran Olahraga. Penerbit Buku Kedokteran EGC.

AlYahya, I. A., Almohsen, H. A., AlSaleem, I. A., Al-Mahid, M. M., Arafah, A. M., AlTurki, Yousef Abdullah, Aljasser, A. A., \& Alkharfi, M. A. (2019). Assessment of knowledge, attitude, and practice about first aid among male school teachers and administrators in Riyadh, Saudi Arabia.
Journal of Family Medicine and Primary Care, 8(2), 684-688.

Arikunto, S. (2011). Prosedur Penelitian: Suatu Pendekatan Praktik (Rev VI). Rineka Cipta.

Arinda, E. N. (2014). Analisis Cedera Olahraga dan Pertolongan Pertama Pemain Sepak Bola. Jurnal Kesehatan Olahraga, 2(3), 179-188.

Bahruddin, M. (2013). Penanganan cedera olahraga pada atlet (pplm) dan (ukm) ikatan pencak silat indonesia dalam kegiatan kejurnas tahun 2013. Unesa, 2, 1-11.

Barutcu, C. D., Dilek, G. A., Cakmak, O., Koksoy, S., \& Polat, M. (2017). Level of Knowledge and Factors Affecting First Aid in Vocational High School Students. International Journal of Caring Sciences, 10(3), 1563-1568.

Dimyati, A. (2018). Pembelajaran Penjasorkes Di Sekolah Dasar Se - Kecamatan Telagasari. Jurnal Speed, 1(1), 1-6.

Elmagd, M. A. (2016). Common Sports Injuries. International Journal of Physical Education, Sports and Health, 3(5), 142148.

Hardyanto, J., \& Nirmalasari, N. (2020). Gambaran Tingkat Pengetahuan Tentang Penanganan Pertama Cedera Olahraga Pada Unit Kegiatan Mahasiswa (Ukm) Olahraga Di Universitas Jenderal Achmad Yani Yogyakarta. Jurnal Kesehatan Mesencephalon, 6(1).

Hastuti, D. (2017). Hubungan Pengetahuan Tentang Antisipasi Cedera Dengan Praktik Pencegahan Cedera Pada Anak Usia Toddler Di Rw 01 Kelurahan Manggahang Wilayah Puskesmas Jelekong Kabupaten Bandung. Jurnal Keperawatan Komprehensif, 3(1), 52-62.

Ismunandar, H. (2020). Cedera Olahraga Pada Anak Dan Pencegahannya. Jurnal Kedokteran Universitas Lampung, 4(1), 
$34-44$.

Khadavi, M. R., \& Ulfah, W. A. (2019). Workshop Pelatihan Pencegahan Dan Perawatan Cidera (PPC) Guru Pendidikan Jasmani Sekolah Dasar Kecamatan Gerunggung Kota Pangkalpinang. Jurnal Pengabdian Masyarakat, 3, 1-25.

Lubis, P., Hasanah, O., \& Dewi, A. P. (2015). Gambaran Tingkat Risiko Cedera pada Anak Usia Sekolah. Journal Online Mahasiswa, 2(2), 1335-1344.

Meikahani, R., \& Kriswanto, E. S. (2015). Pengembangan buku saku pengenalan pertolongan untuk siswa sekolah menengah pertama. Jurnal Pendidikan Jasmani Indonesia, 11(1), 15-22.

Mobarak, A. S., Afifi, R. M., \& Qulali, A. (2015). First Aid Knowledge and Attitude of Secondary School Students in Saudi Arabia. Health, 07(10), 1366-1378.

Mukrim, H., Suriah, \& Nurlinda, A. (2017). Pengaruh Edukasi Menggunakan Video Terhadap Pengetahuan tentang Cedera Olahraga, Intesitas Latihan dan Pola Tidur pada Atlet Klub Bola Voli UNHAS Makassar. Jurnal Ilmiah Kesehatan Diagnosis, 11(4), 417-422.

Mustofa, P. S. (2017). Pembelajaran Pertolongan Pertama dan Pencegahan Perawatan Cedera Olahraga (PP \& PPCO) Berbasis Blended Learning. Pascasarjana, Universitas Negeri Malang.

Okta, R. P., \& Hartono, S. (2020). Tingkat Pengetahuan Penanganan Cedera Olahraga pada Mahasiswa. Jurnal Kesehatan Olahraga, 8(2), 101-108.

Rössler, R., Donath, L., Verhagen, E., Junge, A., Schweizer, T., \& Faude, O. (2014). Exercise-Based Injury Prevention in Child and Adolescent Sport: A Systematic Review and Meta-Analysis. Sports Medicine, 44(12), 1733-1748.

Rössler, R., Junge, A., Chomiak, J., Němec, K., Dvorak, J., Lichtenstein, E., \& Faude, O. (2018). Risk Factors for Football Injuries In
Young Players Aged 7 to 12 Years. Scandinavian Journal of Medicine \& Science in Sports, 28(3), 1176-1182.

Sa'roni, A. S., \& Graha, A. S. (2019). Efektifitas Masase Terapi Cedera Olahraga terhadap Nyeri Tumit dan Nyeri Otot Tibialis pada Atlet Futsal SMAN 1 Ciamis. Medikora, XVIII(2), 56-63.

Saputra, W. (2017). Efek Mengikuti Ektrakurikuler Olahraga Dan Tingkat Kebugaran Jasmani Terhadap Pembentukan Self-Esteem Siswa Di Sekolah Menengah Kejuruan (Smk). Didaktik: Jurnal Ilmiah PGSD STKIP Subang, 3(1), 126-145.

Sari, R. M., \& Purnawan, D. (2017). Survey Pengetahuan Atlet Tentang Cedera Olahraga Pada Klub-Klub Bola Voli Di Kota Stabat Tahun 2015. Jurnal Kesehatan Dan Olahraga, 1(2), 52-60.

Shinde, V. S. (2015). Knowledge Of High School Students In Pune About First Aid And The Effect Of Training On Them. Indian Journal of Basic and Applied Medical Research, 5(1), 556-559.

Simatupang, N. (2016). Pengetahuan Cedera Olahraga Pada Mahasiswa Fakultas Ilmu Keolahrgaan UNIMED. Jurnal Pedagogik Keolahragaan, 02(01), 31-42.

Stracciolini, A., Sugimoto, D., \& Howell, D. R. (2017). Injury prevention in youth sports. Pediatric Annals, 46(3), e99-e105.

Triyani, E., \& Ramdani, M. L. (2020). Pengaruh Pendidikan Kesehatan Terhadap Pengetahuan dan Keterampilan Pertolongan Pertama Cedera Olahraga dengan Metode Prices Pada Anggota Futsal. Jurnal Keperawatan Muhammadiyah, September, 377-384.

Walker, B. (2013). The anatomy of stretching your illustrated guide to flexibility and injury rehabilitation. Lotus Publishing.

Wawan, A., \& Dewi, M. (2011). Teori \& Pengukuran Pengetahuan, Sikap dan Perilaku Manusia Dilengkapi Contoh Kuesioner (Cet. 2). Nuha Medika. 
Wijaya, I. M. K., Wahyuni, P. D. S., Setiawan, K. H., \& Giri, M. K. W. (2019). Pelatihan Pertolongan Pertama Pada Cedera Olahraga Bagi Siswa dan Guru Sekolah Dasar Kecamatan Negara. Senadimas, 488-495.

Wulandini, P., Fitri, A., \& Sari, T. K. (2019). Pengetahuan Siswa/I tentang Pertolongan Pertama pada Kecelakaan saat Berolahraga di SMA Olahraga Rumbai Pekanbaru Provinsi Riau 2019. Jurnal Keperawatan Abdurrab, 3(1), 70-77. 